\title{
Application of the Returning Visit System of Graduates to Promote the Professional Construction and Reform in Colleges and Universities_Guided by "Internet +"
}

\author{
Chen Chen \\ Jilin University of Finance and Economics; Public Foreign Language Teaching and Research \\ Department, Changchun, Jilin, China, 130012
}

Keywords: graduates return visit; e-commerce; teaching reform; information system

\begin{abstract}
This paper starts with the employment situation of e-commerce graduates in recent years, focuses on the analysis of the reasons for the low employment rate of e-commerce graduates with the guidance of "Internet +", proposes to promote teaching through the establishment of graduates returning mechanism reform to improve the employment rate of the solution, and the core idea of constructing the feedback system of graduates returning to the information system, and puts forward the "Internet +"-oriented recommendations for college professional construction and reform for readers' reference.
\end{abstract}

\section{Introduction}

In the era of "Internet $+"$ big data, many schools conduct irregular visits to graduates to understand the work of graduates and care about their work and life. Through the establishment of a graduate employment return mechanism, schools, employers and graduates have established long-term and continuous contacts. This will not only provide a comprehensive understanding of the work and development of graduates, but also test and examine the educational effects of the school $^{[1]}$. It also provides a basis for schools to timely adjust the content of teaching reforms such as training plans and curriculums according to market demand, and comprehensively improve the quality of education, thus cultivating more outstanding graduates who are welcomed by the society.

\section{Analysis of employment situation of e-commerce graduates in recent years}

Through the questionnaire survey and telephone interviews of the e-commerce graduates of e-commerce majors in some universities in Jiangxi Province, the employment situation of e-commerce graduates is shown in Table 1: 
Table 1 Survey data of graduates returning to the system under the background of "Internet +" [1]

\begin{tabular}{|c|c|c|c|c|c|}
\hline \multirow{2}{*}{ Year } & \multirow{2}{*}{$\begin{array}{l}\text { Number } \\
\text { of } \\
\text { students } \\
\text { in school }\end{array}$} & \multicolumn{2}{|c|}{ Number of employed people } & \multirow{2}{*}{$\begin{array}{l}\text { Employment } \\
\text { rate }\end{array}$} & \multirow{2}{*}{$\begin{array}{l}\text { Number of } \\
\text { counterpart } \\
\text { employmen }\end{array}$} \\
\hline & & $\begin{array}{c}\text { Direct } \\
\text { employment }\end{array}$ & $\begin{array}{l}\text { Continuing } \\
\text { Education }\end{array}$ & & \\
\hline 2015 & 228 & $126+7+38$ & $18+20$ & $91.67 \%$ & 173 \\
\hline 2016 & 218 & $111+12+4$ & $60+12$ & $92.56 \%$ & 161 \\
\hline 2017 & 293 & $107+17+10$ & $126+12$ & $92.83 \%$ & 219 \\
\hline
\end{tabular}

Description:

1) Number of employed persons $=$ number of direct employment + number of people continuing to receive education.

2) Direct employment $=$ school recommended employment + self-employment + other channels of employment.

3) Number of people who continue to receive education $=$ " $3+2$ "people + number of students attending school ${ }^{[1]}$.

Through the analysis of Table 1 and the survey results, the following conclusions can be drawn:

\subsection{The employment situation of the 6th consecutive e-commerce profession is not very satisfactory.}

Although the vast majority of graduates are employed, the employment rate is very low. On average, only $28 \%$ of graduates (including counterparts in e-commerce, technology and e-commerce) are engaged in e-commerce. The rest are engaged in non-e-commerce professional work $^{[2]}$.

\subsection{The professional requirements for students are getting higher and higher in the context of "Internet +"}

In 2000, Chinese colleges and universities began to recruit e-commerce majors. However, because of the lack of understanding of the profession at the beginning, the social needs at that time were not clear, and there were few employers directly recruiting e-commerce posts, which led to the early e-commerce graduates. In the past few years, with the rapid development of China's Internet, the improvement of people's living standards and the gradual acceptance of online shopping models, the professional positioning of e-commerce has become more and more clear, and many enterprises have begun to involve e-commerce ${ }^{[3]}$. The demand for direct recruitment of e-commerce talents, the demand for pre-bias technology is greater than the demand for partial business. In recent years, the demand for online commerce on the basis of knowing technology has gradually increased.

\section{Put forward the problem of college professional construction with the development of "Internet +"}

\subsection{Current status of college professional construction in China}

According to statistics, there are more than 10 million registered e-commerce enterprises in China, including more than 100,000 large and medium-sized enterprises. It is estimated that the demand for e-commerce talents in China will be about 200,000 per year, and the current annual output is the number of talents is about 100,000, and the shortage of talents will become a 
bottleneck restricting the development of China's e-commerce. As a result, the e-commerce graduates who have been trained cannot adapt to the needs of the talent market ${ }^{[4]}$.

\subsection{Solutions to increase employment rates in the context of "Internet Plus"}

Everyone often attributed the difficulty in employment of e-commerce graduates to colleges and universities. It is believed that most colleges and universities have a vague goal in cultivating e-commerce, and the orientation of training is unclear. The deviation of professional understanding is the main reason. In response to these complaints, the heads of colleges and universities also have difficulties. They learn from each other and continue to carry out teaching reforms, but they always have no way to go. The root cause lies in the fact that this kind of closed-ended teaching reform cannot keep up with the development of the times due to the lack of adjustment and guidance of social factors. The rhythm, because there is no good circular feedback mechanism, the school, the employer, the graduates and the students in the school are seriously out of touch, the talents cultivated by the university will never meet the requirements of social needs, as shown in Figure 1:

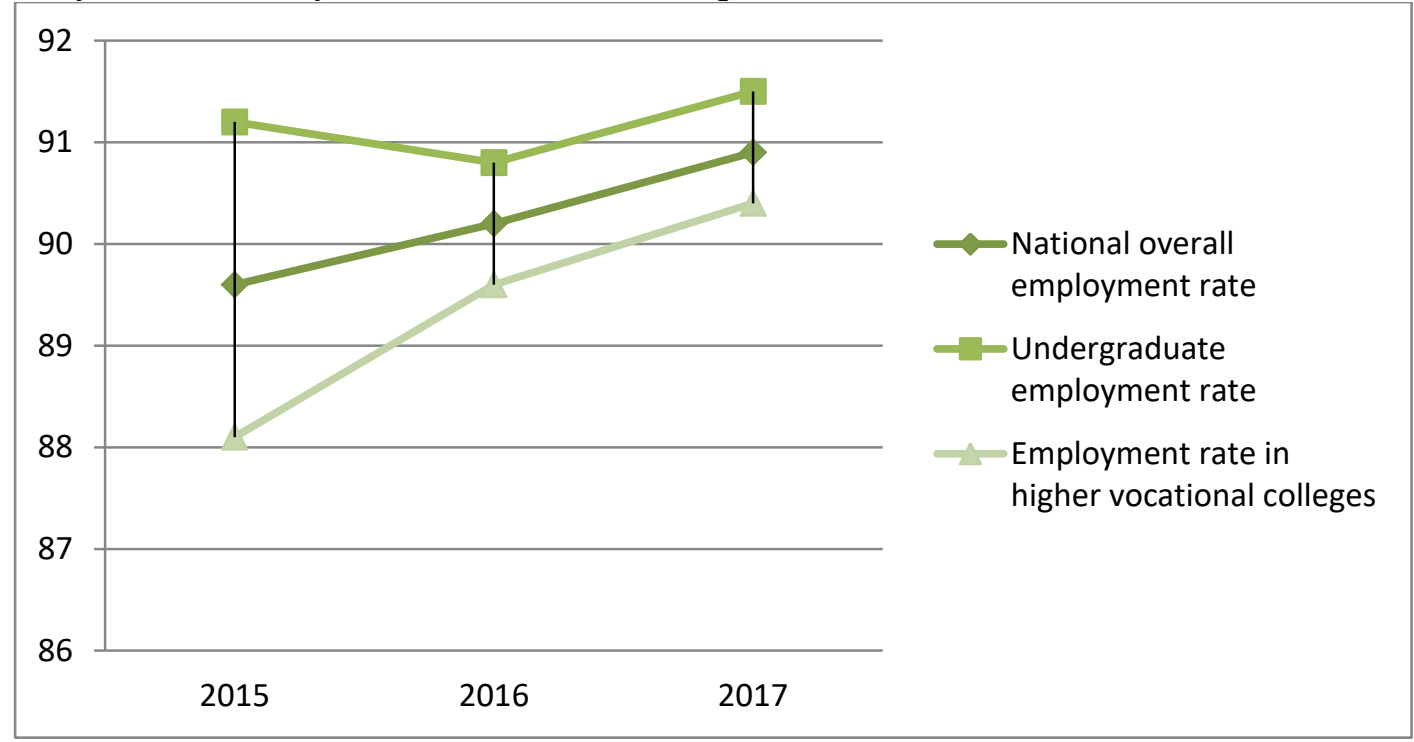

Figure 1 Statistical Analysis of Improving Employment Rate in the Background of "Internet +" [4]

In the above state presented in Figure 2, whether it is colleges, students, graduates or employers are confused, the main problems they currently have are as follows:

\subsubsection{College aspects}

At present, the setting of most e-commerce courses in colleges and universities is basically based on economic plus computer professional knowledge. The goal is to cultivate a combination of traditional means and modern means, but the simple accumulation of knowledge and fragmentation leads to students compounding. It is not systematic and professionally proficient, and has become a marginal talent for non-economic and non-computer majors; the content of the course and the content of social needs are seriously out of line, and e-commerce is a comprehensive subject, requiring a large number of training activities ${ }^{[4]}$.

$\checkmark$ Feedback from graduates and employers will be an important reference for school teaching reform;

- Positioning e-commerce talent training goals according to the needs of society;

- Adjust the training plan according to the requirements of the employer.

Although many colleges and universities have realized this problem in recent years, they have set 
up e-commerce labs and installed some professional teaching software for students to practice exercises. However, this software's are out of the actual business environment and cannot keep up with the development of existing applications. Let students actually feel the application of e-commerce in reality, sometimes they have not graduated from the knowledge they have graduated; the school lacks effective means of school-enterprise cooperation, and some school-enterprise cooperation mostly stays in students' study and internships, lacking deep level Cooperation will greatly affect the cultivation of talents and employment ${ }^{[5]}$.

\subsubsection{Employer aspects}

Many employers do not really understand e-commerce, do not make good use of the network to carry out e-commerce, most enterprises have low levels of application of e-commerce, many still stay in the construction of websites, do propaganda, do not really use e-commerce for online transactions and Deep application:

- Keep abreast of the school's scientific research trends and actively seek college cooperation projects;

- Dynamically participate in the optimization of talent training programs in colleges and universities, and provide practical guidance for the reform of colleges and universities;

- Regularly release talent demand standards, expand recruitment channels, and attract talented people to come to work ${ }^{[5]}$.

In recent years, some enterprises are in great need of e-commerce talents to expand their business, but because of the lack of understanding of e-commerce concepts and the level of application, they do not understand what e-commerce professionals can do? How to use? Should it be placed in the marketing department or the technical department?

\subsubsection{E-commerce graduates}

E-commerce graduates tend to be unclear about the number of jobs and the employment prospects are confused. Many students don't know their employment direction, and they don't know what ability and certificate they should get in order to make themselves more competitive. They don't know how to apply for a suitable position; don't know what they can do and the future. The goal of life struggle should be improved from the following aspects:

$\checkmark$ Improve the experience through the experience and experience of the graduates;

- Understand the employment direction and prospects of this major;

- Understand the needs of the company, adjust your study plan in time, and take less detours.

Although there are a few colleges and universities that have a sense of returning visits, the scope of return visits is too narrow. It is limited to some liaisons with some well-known graduates. Their return visits are limited to invitations to return to make a report, attending the ceremony, etc. Some colleges and universities use the method of establishing alumni network to realize the form of returning visits ${ }^{[5]}$. However, there are generally many problems in the construction of website content, such as imperfect construction, imperfect functions, imperfect functions, little help to teaching reform, and valuable information.

\subsubsection{E-commerce in school}

The students of this major generally stay in the study of books, do not value or cherish the practice of teaching; learning is still in the state of following the teacher, active learning is not strong, information awareness is weak; learning methods are backward, there is no system for learning Sexuality and lack of mastery of the profession, learning is very blind; the content of learning cannot keep pace with the times, and the knowledge and skills that are urgently needed by 
the employers are not learned, and the ability to work independently is poor ${ }^{[4]}$. Therefore, it is urgent to solve the disconnection between the talent training department and the social employer, and to build a feedback mechanism for graduates with complete content and perfect mechanism.

\section{Conclusions}

Through the investigation of this project, it is found that most colleges and universities in China have not established a mechanism for returning graduates. For many graduates, there are no or very general schools. What students have gone to graduates, what units have been changed in the middle, now where, contact information, etc. are blank, let alone talk back to them.

By setting up a special institution in the school, the institution can be managed at the admissions and employment office. It can also be managed in the administrative management department or in a separate department. The realization can be solved by establishing a feedback system based on the $\mathrm{B} / \mathrm{C}$ model. This system should be able to integrate graduates, companies, school students, school teachers and schools to achieve a win-win situation through this platform.

\section{Acknowledgements}

Construction of graduation return visit system based on Internet + and analysis of its active role in professional development, JJKH20190745SK

\section{References}

[1] Triola M M, Hawkins R E, Skochelak S E. The Time Is Now: Using Graduates' Practice Data to Drive Medical Education Reform.[J]. Academic Medicine, 2018:1.

[2] Passaretta G, Trivellato P, Triventi M. Between academia and labour market-the occupational outcomes of PhD graduates in a period of academic reforms and economic crisis[J]. Higher Education, 2018(3):1-19.

[3] Camargo P P. Understanding the space of nursing practice in Colombia: A critical reflection on the effects of health system reform.[J]. Nursing Inquiry, 2018, 36(C):e12242.

[4] Ran J. Seizing the SPOC opportunity and promoting reform of university computer foundation teaching in independent colleges[C]// International Conference on Computer Science \& Education. 2017.

[5] Slonimczyk F, Francesconi M, Yurko A V. Moving on Up for High School Graduates in Russia: The Consequences of the Unified State Exam Reform[J]. Marco Francesconi, 2017. 